\title{
Influences of surface coatings and components of FePt nanoparticles on the suppression of glioma cell proliferation
}

This article was published in the following Dove Press journal:

International Journal of Nanomedicine

28 June 2012

Number of times this article has been viewed

\author{
Haiming Sun ${ }^{1, *}$ \\ Xiaohui Chen ${ }^{2, *}$ \\ Dan Chen' \\ Mingyan Dong' \\ Xinning $\mathrm{Fu}^{\prime}$ \\ Qian $\mathrm{Li}^{\prime}$ \\ Xi Liu' \\ Qingzhi Wu' \\ Tong Qiu' \\ Tao Wan' \\ Shipu Li'
}

'State Key Laboratory of Advanced Technology for Materials Synthesis and Processing and Biomedical Materials and Engineering Center, Wuhan University of Technology, Wuhan, China; ${ }^{2}$ Department of Prosthetics, School of Stomatology, Wuhan University, Wuhan, China

*Both authors contributed equally to this work
Correspondence: Qingzhi Wu; Shipu Li State Key Laboratory of Advanced Technology for Materials Synthesis and Processing and Biomedical Materials and Engineering Center, Wuhan University of Technology, Wuhan 430070, China

Tel +86 278765 I852

Fax +86 2787880734

Email wuqzh@whut.edu.cn; lishipu46@I26.com
Abstract: Malignant gliomas are primary brain tumors with high rates of morbidity and mortality; they are the fourth most common cause of cancer death. Novel diagnostic and therapeutic techniques based on nanomaterials provide promising options in the treatment of malignant gliomas. In order to evaluate the potential of FePt nanoparticles (NPs) for malignant glioma therapy, FePt NPs with different surface coatings and components were tunably synthesized using oleic acid/oleylamine (OA/OA) and cysteines (Cys) as the capping agents, respectively. The samples were characterized using X-ray diffraction, transmission electron microscopy (TEM), $\mathrm{X}$-ray photon spectroscopy, Fourier transform infrared spectroscopy, atomic absorption spectrum, and zeta potential. The influence of the surface coatings and components of the FePt NPs on the proliferation of glioma cells was assessed through MTT assay and TEM observation using three typical glioma cell lines (glioma U251 cells, astrocytoma U87 cells, and neuroglioma H4 cells) as in vitro models. The results showed that the proliferation of glioma cells was significantly suppressed by lipophilic FePt-OA/OA NPs in a time- and/or dose-dependent manner, while no or low cytotoxic effects were detected in the case of hydrophilic FePt-Cys NPs. The $\mathrm{IC}_{50}$ value of FePt-OA/OA NPs on the three glioma cell lines was approximately $5-10 \mu \mathrm{g} \mathrm{mL}^{-1}$ after 24 hours' incubation. Although the cellular uptake of FePt NPs was confirmed regardless of the surface coatings and components of the FePt NPs, the suppression of FePt NPs on glioma cell proliferation was dominantly determined by their surface coatings rather than their components. Therefore, these results demonstrate that, through engineering of the surface coating, FePt NPs can potentially be developed as novel therapeutic agents for malignant gliomas.

Keywords: FePt nanoparticles, surface coatings, compositions, glioma cells, proliferation

\section{Introduction}

Malignant gliomas are primary brain tumors with high rates of morbidity and mortality; they are the fourth most common cause of cancer death. ${ }^{1-3}$ However, progress in the clinical diagnosis of and therapy for malignant gliomas has lagged behind that of other cancers due to their complicated pathogenesis and the obstacles posed by the blood-brain barrier. Novel diagnosis and therapeutic techniques based on nanomaterials provide promising options for treatment of malignant gliomas. ${ }^{4-6}$ In addition to various nanocarriers for drug delivery, noble metal and oxide nanoparticles (NPs) (such as $\mathrm{Au}, \mathrm{Ag}$, and $\mathrm{Fe}_{2} \mathrm{O}_{3} \mathrm{NPs}$ ) have displayed promising potential in the diagnosis and therapy of malignant gliomas. ${ }^{7-9}$ Magnetothermal- and photothermal-mediated hyperthermia has proved to be efficient in the promotion of glioma cell death, the reduction of gliomal masses, and an increase in survival rate in most preclinical and clinical experiments. ${ }^{10}$ For example, using a supramolecular self-assembly approach, Au NPs ( $\sim 2 \mathrm{~nm})$, functionalized with a polymer shell 
and target-specific ligand, significantly enhance photothermal treatment on U87 and MCF7 cells. ${ }^{11} \mathrm{TiO}_{2} \mathrm{NPs}$, covalently modified with an antibody (antihuman-IL13 $\alpha 2 \mathrm{R}$ ), can bind exclusively to glioma cells and initiate the production of intracellular reactive oxygen species under visible light irradiation, which subsequently results in oxidative damage to organelles and cell apoptosis. ${ }^{12}$ To date, exploration of multifunctional nanomaterials for targeted diagnosis of and therapy for malignant gliomas is one of the most emergent challenges.

Superparamagnetic FePt NPs have attracted considerable attention due to their tempting potential in biomedical fields. For example, a sensitive and quick assay capturing both Gram-negative and Gram-positive bacteria was developed by combining vancomycin with the surface of FePt NPs. ${ }^{13-15}$ Similarly, FePt NPs have been used to magnetically separate and detect proteins and DNA. ${ }^{16-18}$ The magnetization of FePt NPs up to $\sim 1000 \mathrm{emu} \mathrm{cc}^{-1}$ is higher than that of commonly used iron oxide (approximately 300-400 emu cc ${ }^{-1}$ ) and comparable to that of $\mathrm{Co}\left(\sim 1400 \mathrm{emu} \mathrm{cc}^{-1}\right)$ and Fe $(\sim 1700 \mathrm{emu}$ $\mathrm{cc}^{-1}$ ), making them valuable candidates for magnetic resonance imaging. ${ }^{19-22}$ It has been reported that FePt NPs display stronger contrast enhancement when compared with several commercial magnetic resonance imaging contrast agents (Feridex, MION, and Sinerem; AMAG Pharmaceuticals Inc., Lexington, MA, MGH Center of Molecular Imaging Research, Boston, MA, and Guerbet Group, Villepinte, France, respectively) according to their apparent transverse relaxivity values. ${ }^{19,20}$ Therefore, FePt NPs can serve as dual modality contrast agents for molecular CT (computed tomography molecular imaging or MRI (magnetic resonance imaging) in vitro and in vivo after engineering their surfaces with functional molecules. ${ }^{21}$ Of particular interest, superparamagnetic FePt NPs have been derived from the anticancer activity of FePt NPs. Both FePt@ $\mathrm{CoS}_{2}$ and FePt@ $\mathrm{Fe}_{2} \mathrm{O}_{3}$ yolkshell NPs display a much lower $\mathrm{IC}_{50}$ on HeLa cells than that of cisplatin, according to MTT assay. ${ }^{19,23}$ Additionally, FePt NPs significantly suppress the proliferation of various tumor cells, such as human ovarian cancer cells (A2780), human epithelial carcinoma cells (A431), human breast cancer cells (Sk-Br3), and human embryonic kidney cells (HEK-293). ${ }^{24}$ Thus, superparamagnetic FePt NPs could be considered good candidates for developing multi-functional nanomedicines for the diagnosis and therapy of malignant gliomas.

In the present study, FePt NPs with different surface coatings and components were tunably synthesized using oleic acid/oleylamine (OA/OA) and amino acid (cysteine [Cys]) as capping agents, respectively. The samples were characterized using X-ray diffraction (XRD), transmission electron microscopy (TEM), X-ray photon spectroscopy (XPS), Fourier transform infrared spectroscopy (FTIR), and atomic absorption spectroscopy (AAS). In particular, the suppression of FePt NPs on the proliferation of glioma cells was evaluated by MTT assay using different glioma cell lines (human glioma U251 cells, human astrocytoma U87 cells, and human neuroglioma H4 cells) as models. The influence of the surface coatings and the components of FePt NPs on both suppression and cellular uptake were collectively investigated.

\section{Materials and methods Materials}

Platinum acetylacetonate ( $\left.\mathrm{Pt}[\mathrm{acac}]_{2}, 97 \%\right)$, potassium hexachloroplatinate $\left(\mathrm{K}_{2} \mathrm{PtCl}_{6}, 98 \%\right)$, iron acetylacetonate (Fe(acac) $\left.)_{3}, 99.9 \%\right)$, 1,2-hexadecanediol (90\%), and oleylamine $(\geq 70 \%)$ were used (all from Sigma-Aldrich, St Louis, $\mathrm{MO})$. Other chemicals were of analytical grade and used without further purification. Deionized water $(16 \mathrm{M} \Omega \mathrm{cm})$ was supplied by Nanopure Water Systems UV (Thomas Scientific, Swedesboro, NJ).

\section{Synthesis of FePt NPs coated by oleic acid and oleylamine (FePt-OA/OA NPs)}

FePt-OA/OA NPs were synthesized according to a modified method. ${ }^{25}$ Briefly, Fe(acac) ${ }_{3}(0.5 \mathrm{mmol})$, oleic acid $(400 \mu \mathrm{L})$ and ethylene glycol $(100 \mathrm{~mL})$ were mixed and heated to $150^{\circ} \mathrm{C}$ in a three-necked round-bottom flask in a nitrogen atmosphere. $\mathrm{Pt}(\mathrm{acac})_{2}(0.5 \mathrm{mmol})$ and oleylamine $(400 \mu \mathrm{L})$ were dissolved in another $100 \mathrm{~mL}$ of ethylene glycol at $100^{\circ} \mathrm{C}$, and then transferred to a three-necked round-bottom flask. After both of the solutions containing the iron and platinum salts were mixed completely at $150^{\circ} \mathrm{C}$, 1,2-hexadecanediol $(1.5 \mathrm{mmol})$ was added and dissolved in this mixture. Subsequently, the mixture was heated to $197^{\circ} \mathrm{C}$ at a heating rate of $10^{\circ} \mathrm{C} \mathrm{min}^{-1}$ and refluxed at this temperature for 3 hours. Finally, the heat source was removed and the product was cooled down to room temperature. The black product was precipitated out and washed with ethanol $(200 \mathrm{~mL})$ by centrifugation $(10,000 \mathrm{rpm} \times 5$ minutes $)$.

\section{Synthesis FePt NPs coated by L-cysteine (FePt-Cys NPs)}

The synthetic experiments were carried out using standard airless procedures. In a typical synthesis, L-Cys $(0.1 \mathrm{mmol})$ and $\mathrm{K}_{2} \mathrm{PtCl}_{6}(0.5 \mathrm{mmol})$ were dissolved in $100 \mathrm{~mL}$ deionized water with nitrogen flow $(\sim 5 \mathrm{~mL} / \mathrm{min})$ in a $250 \mathrm{~mL}$ three-neck flask while being magnetically stirred. The mixture was heated 
to $50^{\circ} \mathrm{C}$ to ensure the dissolution of $\mathrm{K}_{2} \mathrm{PtCl}_{6}$ and then cooled down to room temperature. $\mathrm{FeCl}_{2} \cdot 4 \mathrm{H}_{2} \mathrm{O}(0.5 \mathrm{mmol})$ was introduced and dissolved completely in this mixture. Then, $\mathrm{NaBH}_{4}$ ( $5 \mathrm{mmol}$ ) dissolved in $10 \mathrm{~mL}$ of deionized water was added dropwise to the mixture containing the iron and platinum salts, which was then incubated at $25^{\circ} \mathrm{C}$ for 2 hours. The resulting precipitate was centrifuged $(10,000 \mathrm{rpm} \times 3$ minutes $)$, washed several times - alternately using deionized water and ethanol - and dried in a vacuum for 12 hours.

\section{FePt NPs characterization}

The phase structures of the samples were identified by powder XRD on an X'Pert PRO diffractometer (PANalytical B.V., Almelo, The Netherlands) using $\mathrm{Cu} \mathrm{K} \alpha$ radiation $(\lambda=1.5406 \AA)$. FTIR spectra were recorded with a NEXUS FTIR spectrometer (Thermo Nicolet, Madison, WI). AAS (GBC Avanta M; GBC Scientific Equipment Pty Ltd, Braeside, Australia) was used to analyze the Fe/Pt molar ratios in the samples. TEM (Tecnai G2 20; FEI Company, Eindhoven, The Netherlands) and high-resolution transmission electron microscopy (HRTEM) (JEM-2100F; JEOL, Tokyo, Japan) were used to observe the morphology, particle size, and detailed information about the lattice of the samples. XPS were measured on a VG Multilab 2000 (Thermo Electron Corporation, Waltham, MA) with an $\mathrm{Al} \mathrm{K} \alpha$ excitation source, where the binding energies were calibrated by referencing the $\mathrm{C} 1 \mathrm{~s}$ peak $(285.1 \mathrm{eV})$. Zeta potential was measured on a zeta and size analyzer (Zetasizer 3000; Malvern Instruments Ltd, Malvern, UK).

\section{Cell culture and treatment}

Brain tumor cells (human glioma U251 cells, human astrocytoma U87 cells, and human neuroglioma H4 cells) were purchased from the China Center for Type Culture Collection (CCTCC; Wuhan, China). All cell lines were maintained in MEM (Hyclone Corp., Logan, UT) supplemented with $10 \%$ fetal bovine serum (FBS) $\left(\right.$ Gibco $^{\circledR}$; Life Technologies, Carlsbad, CA), 100 units penicillin $\mathrm{mL}^{-1}$, and $100 \mu \mathrm{g}$ streptomycin $/ \mathrm{mL}$ at $37^{\circ} \mathrm{C}$ with $5 \% \mathrm{CO}_{2}$. Cells were harvested by trypsinizing for 5 minutes at $37^{\circ} \mathrm{C}$ with $0.25 \%$ trypsin (AMRESCO, Solon, OH).

\section{Suppression of FePt NPs in glioma cell proliferation}

In the initial experiments, the possible cytotoxic effects of FePt NPs on U251, U87, and H4 cells were evaluated. We examined the time- and dose-dependent effects induced by FePt NPs on cell viability through MTT assay. According to the results of the pre-trials, different exposed doses and incubation intervals were designed for systematically evaluating the cytotoxic effects of FePt NPs. Cells were seeded at a density of $3 \times 10^{4}$ cells/well in the culture plates and grown for 14 hours before FePt NPs were added. In the case of FePt-OA/OA NPs, cells were treated at doses of approximately $0.1,1,5$, and $25 \mu \mathrm{g} / \mathrm{mL}$ for $6,12,24$, and 48 hours, respectively; in the case of FePt-Cys NPs, cells were treated at doses of approximately $25,50,100$, and $200 \mu \mathrm{g} / \mathrm{mL}$ for 24, 48, and 72 hours, respectively. After the cells were treated with FePt NPs at the designed doses and times, $20 \mu \mathrm{L}$ MTT $(5 \mathrm{mg} / \mathrm{mL})$ were added to each well, and then the plates were incubated in minimum essential medium (MEM) at $37^{\circ} \mathrm{C}$ for 4 hours. Finally, all of the medium was removed; $150 \mu \mathrm{L}$ dimethyl sofoxide (DMSO) was added to each well, and the plates were shaken for $10 \mathrm{~min}$. The absorbance of each well was measured at a wavelength of $550 \mathrm{~nm}$ using a microplate spectrophotometer 1500 (Thermo Labsystems, Finland). Data were expressed as means \pm standard deviation (SD) and oneway analysis of variance (ANOVA) was carried out.

\section{Cellular uptake of FePt NPs}

Cells were treated with different FePt NPs at $25 \mu \mathrm{g} / \mathrm{mL}$ for 24 hours. Then the culture medium was removed. Cells were fixed successively by $4 \%$ glutaraldehyde phosphate buffer at $4^{\circ} \mathrm{C}$ for 4 hours and $1 \%$ osmic acid for 2 hours. Subsequently, the samples were desiccated through a graded ethanol series $(30 \%, 50 \%, 60 \%, 70 \%, 80 \%, 90 \%)$, which were further embedded in EPON812 and polymerized in the oven at $60^{\circ} \mathrm{C}$ for 24 hours. Ultrathin sections of $\sim 70 \mathrm{~nm}$ thick were cut with a diamond knife on a Leica ultramicrotome (Leica Microsystems, Wertzlar, Germany) and transferred to a copper grid. The images were observed by TEM.

\section{Results \\ Synthesis and characterization of FePt NPs}

Figure 1 shows the TEM images of FePt NPs synthesized at different surface coatings and the Fe/Pt molar ratios. As shown in Figure $1 \mathrm{~A}-\mathrm{C}$, the uniform and well-dispersed FePt NPs obtained had a nearly spherical shape and no aggregations were observed due to the surface coating of OA/OA molecules. In the TEM images, the sizes of the FePt NPs corresponding to the initial $\mathrm{Fe} / \mathrm{Pt}$ molar ratios of $3: 1,1: 1$, and $1: 3$ were approximately $4.3 \pm 0.5,7.1 \pm 0.9$ and $3.6 \pm 0.4 \mathrm{~nm}$, respectively. Similarly, few aggregates of FePt NPs were observed when OA/OA was replaced with Cys, which could be attributed to an interparticle repulsive force derived from 

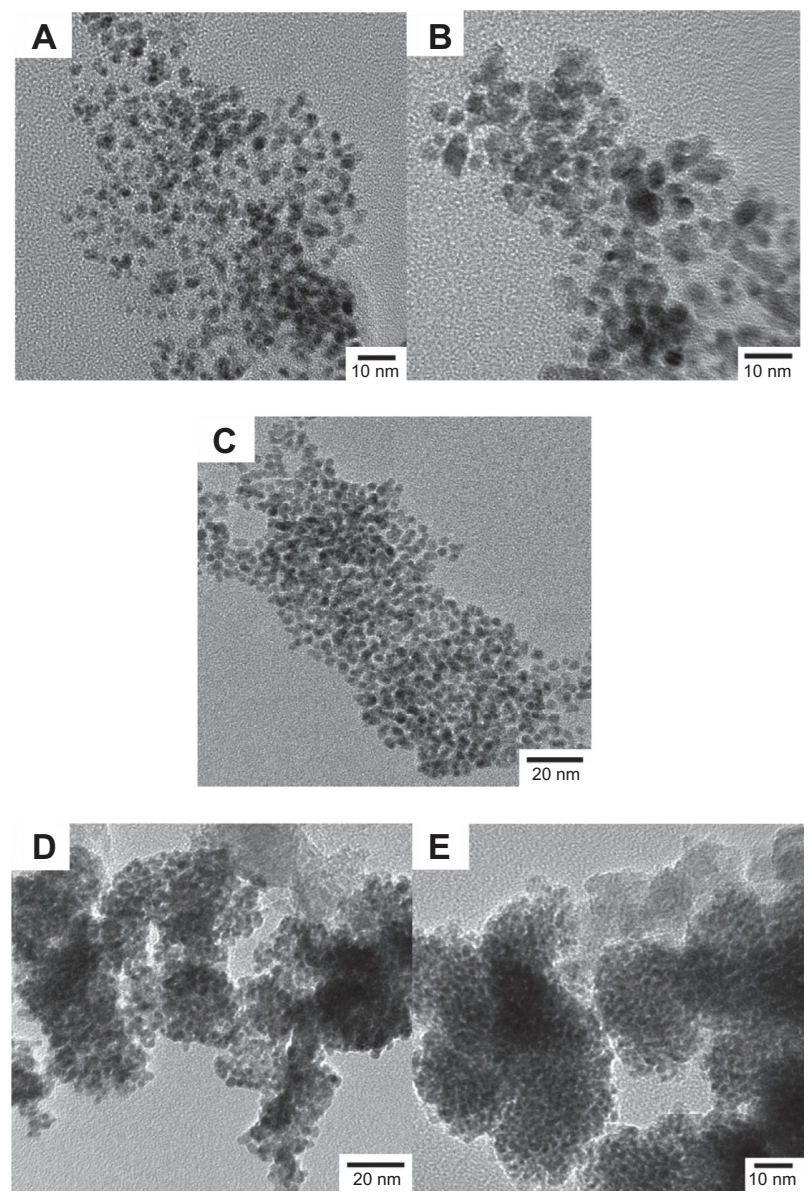

Figure I TEM images of FePt NPs synthesized with different Fe/Pt molar ratios and surface coatings.

Notes: (A) Fe:Pt = 3:I, OA/OA; (B) Fe:Pt = I:I, OA/OA; (C) Fe:Pt = I:3, OA/OA; (D) Fe:Pt = I:I, Cys; (E) Fe:Pt = I:3, Cys.

Abbreviations: TEM, transmission electron microscopy; NPs, nanoparticles; OA/ OA, oleic acid/oleylamine; Cys, cysteine.

the highly negatively charged surfaces (as will be discussed later). In the TEM images, the sizes of the FePt NPs synthesized with different $\mathrm{Fe} / \mathrm{Pt}$ molar ratios and surface coatings of $1: 1$ and 1:3 were approximately. $3.1 \pm 0.4$ and $3.4 \pm 0.3 \mathrm{~nm}$, respectively (Figure 1D and E).

The phase structures of the as-synthesized samples were identified by powder XRD. All peaks in Figure 2A-C could be assigned to planes of (111), (200), (220), and (311) of the chemically disordered face-centered cubic structure of FePt. ${ }^{26-29}$ No additional peak attributed to iron oxide or pure Pt was observed in the XRD patterns. It is apparent that only the main peak assigned to the (111) plane was distinguished when OA/OA molecules were replaced with Cys molecules (Figure 2D and E), suggesting poor crystal structure due to the low synthesis temperature (room temperature). As shown in Table 1, the sizes of the FePt NPs calculated according to the Debye-Scherrer formula were slightly larger than those obtained from the TEM images.

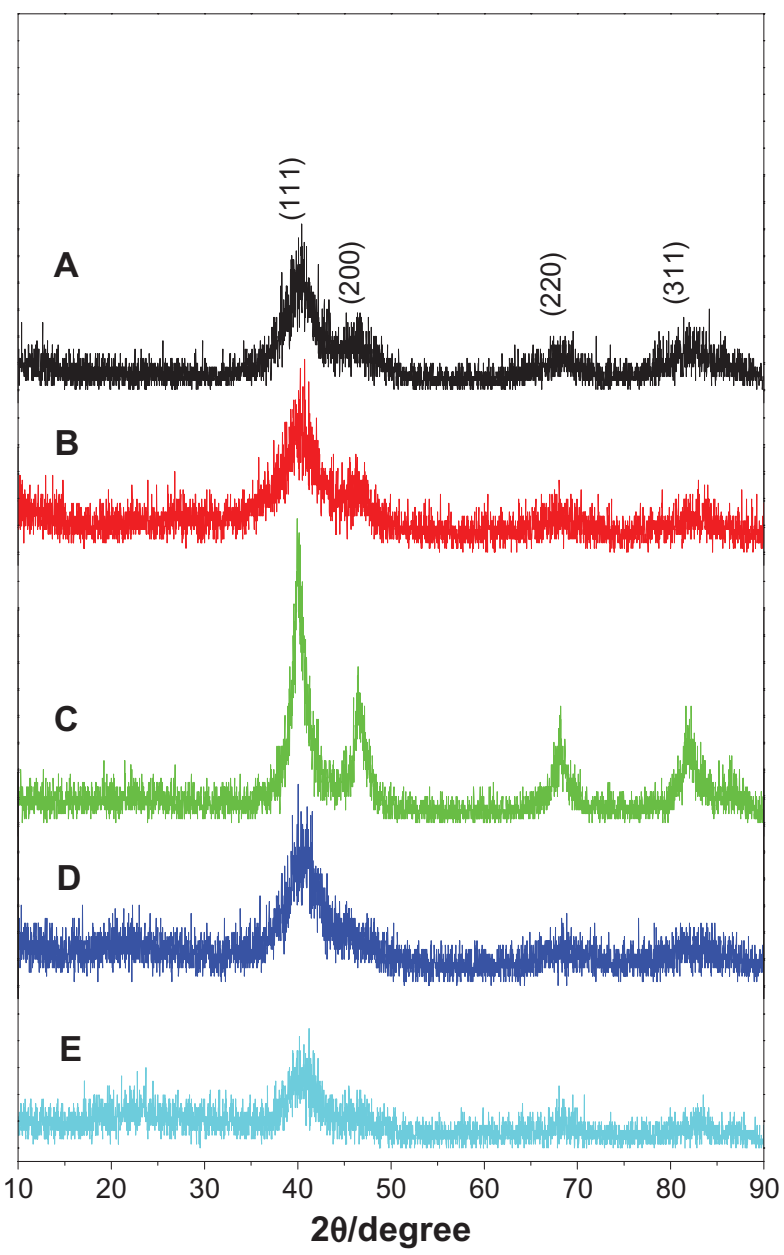

Figure 2 XRD patterns of FePt NPs synthesized at different Fe/Pt molar ratios and with different surface coatings.

Notes: (A) Fe:Pt = 3:I, OA/OA; (B) Fe:Pt = I:I, OA/OA; (C) Fe:Pt = I:3, OA/OA; (D) Fe:Pt = I:I, Cys; (E) Fe:Pt = I:3, Cys.

Abbreviations: XRD, X-ray diffraction; NPs, nanoparticles; OA/OA, oleic acid/ oleylamine; Cys, cysteine.

The Fe/Pt atomic ratios in the FePt NPs were measured by AAS. Table 1 summarizes the Fe/Pt molar ratios in the precursors and FePt NPs. The Fe/Pt molar ratios of the FePt NPs were slightly different from those of the precursors. This could be attributed to the different chemical activities of $\mathrm{Fe}$ and Pt ions in the formation and growth of alloy nuclei. ${ }^{26,30}$ In context, FePt NPs with different surface coatings were denoted as $\mathrm{Fe}_{\mathrm{x}} \mathrm{Pt}_{100-\mathrm{x}}-\mathrm{OA} / \mathrm{OA}$ NPs or $\mathrm{Fe}_{\mathrm{x}} \mathrm{Pt}_{100-\mathrm{x}}-\mathrm{Cys} \mathrm{NPs}$.

The chemical states of Fe and Pt elements in the FePt NPs were detected by XPS. As shown in Figure 3, the Pt $4 \mathrm{f}$ signal was split into two spin-orbit doublets $\left(4 \mathrm{f}_{7 / 2}\right.$ and $\left.4 \mathrm{f}_{5 / 2}\right)$ with maxima at approximately $71.0-71.5 \mathrm{eV}$ and $74.1 \sim 74.8 \mathrm{eV}$, corresponding to the samples synthesized at different surface coatings and Fe/Pt molar ratios. The slight shift of $\mathrm{Pt}$ $4 \mathrm{f}$ binding energy compared with that of bulk Pt was attributed to the adsorption of capping molecules through $-\mathrm{NH}_{2}$ in oleylamine molecules or $-\mathrm{SH}$ in Cys molecules. ${ }^{26,31-33}$ 
Table I Compositions and sizes of FePt NPs synthesized at different Fe/Pt ratios and surface coatings

\begin{tabular}{|c|c|c|c|c|c|c|c|}
\hline \multirow[t]{2}{*}{ Sample } & \multicolumn{2}{|c|}{ Precursors and molar ratio } & \multirow[t]{2}{*}{ Capping agent } & \multirow[t]{2}{*}{ Fe/Pt molar ratio } & \multirow{2}{*}{$\begin{array}{l}\text { Composition } \\
\left(\mathrm{Fe}_{\mathrm{x}} \mathrm{Pt}_{100-\mathrm{x}}\right)^{\mathrm{c}}\end{array}$} & \multicolumn{2}{|c|}{ Diameter (nm) } \\
\hline & & & & & & $\mathbf{X R D}^{\mathrm{d}}$ & TEM $^{\mathrm{e}}$ \\
\hline $\mathrm{I}^{\mathrm{a}}$ & \multirow[t]{3}{*}{$\mathrm{Fe}(\mathrm{acac})_{3} / \mathrm{Pt}(\mathrm{acac})_{2}$} & $3: 1$ & \multirow[t]{3}{*}{ OA/OA } & $60: 40$ & $\mathrm{Fe}_{60} \mathrm{Pt}_{40}-\mathrm{OA} / \mathrm{OA}$ & 5.8 & $4.3 \pm 0.5$ \\
\hline $2^{\mathrm{a}}$ & & $\mathrm{I}: \mathrm{I}$ & & $45: 55$ & $\mathrm{Fe}_{45} \mathrm{Pt}_{55}-\mathrm{OA} / \mathrm{OA}$ & 7.7 & $7.1 \pm 0.9$ \\
\hline $3^{\mathrm{a}}$ & & $\mathrm{I}: 3$ & & $27: 73$ & $\mathrm{Fe}_{27} \mathrm{Pt}_{73}-\mathrm{OA} / \mathrm{OA}$ & 5.6 & $3.6 \pm 0.4$ \\
\hline $4^{b}$ & \multirow{2}{*}{$\mathrm{FeCl}_{2} / \mathrm{K}_{2} \mathrm{PtCl}_{6}$} & $\mathrm{I}: \mathrm{I}$ & \multirow[t]{2}{*}{ Cys } & $60: 40$ & $\mathrm{Fe}_{60} \mathrm{Pt}_{40}-\mathrm{Cys}$ & 4.6 & $3.1 \pm 0.4$ \\
\hline $5^{b}$ & & $\mathrm{I}: 3$ & & $24: 76$ & $\mathrm{Fe}_{24} \mathrm{Pt}_{76}-\mathrm{Cys}$ & 4.2 & $3.4 \pm 0.3$ \\
\hline
\end{tabular}

Notes: aSamples were synthesized using a polyol reduction route under refluxing temperature; 'samples were synthesized using $\mathrm{NaBH} 4$ as the reductant at room temperature; ${ }^{c}$ in context, FePt NPs with different surface coatings were denoted as $\mathrm{Fe}_{x} \mathrm{Pt}_{100-x}-\mathrm{OA} / \mathrm{OA} \mathrm{NPs}$ or $\mathrm{Fe}_{\mathrm{x}} \mathrm{Pt}_{100-\mathrm{x}}-\mathrm{C}_{\mathrm{s}} \mathrm{NPs}$ for convenience; ${ }^{\mathrm{d}}$ sizes of NPs were calculated from XRD patterns according to the Debye-Scherrer formula; ${ }^{e}$ sizes of NPs were obtained from TEM images.

Abbreviations: NPs, nanoparticles; OA/OA, oleic acid/oleylamine; Cys, cysteine; XRD, X-ray diffraction; TEM, transmission electron microscopy

Similarly, the Fe $2 \mathrm{p}$ signal was split into two $\left(2 \mathrm{p}_{3 / 2}\right.$ and $\left.2 \mathrm{p}_{1 / 2}\right)$ with maxima at approximately. 710.4-711.5 eV and 724.5$725 \mathrm{eV}$ due to spin-orbit coupling. The formation of Fe-O bonds due to the surface coating of OA/OA or Cys molecules resulted in a slight shift of binding energy when compared with that of neutral $\mathrm{Fe}^{26,31-33}$

The existence of capping molecules on the surface of the FePt NPs was further confirmed by FT-IR spectra. The absorption at $\sim 3400 \mathrm{~cm}^{-1}$ in the FTIR spectra of the FePt-OA/OA NPs could be attributed to the $\mathrm{N}-\mathrm{H}$ stretching of oleylamine, while absorption at $\sim 2920$ and $\sim 2850 \mathrm{~cm}^{-1}$ could be assigned to the symmetric and asymmetric $-\mathrm{CH}_{2}$ stretching modes in the OA/OA molecules (Figure 4). It is worthy of note that the absorption at $\sim 1709 \mathrm{~cm}^{-1}$ derived from the $\mathrm{C}=\mathrm{O}$ stretching mode of oleic acid (Figure $4 \mathrm{E}$ ) was shifted to $\sim 1650 \mathrm{~cm}^{-1}$ in the FTIR spectra of FePt-OA/OA NPs (Figure 4A-C), suggesting the chemical adsorption of oleic acid as a carboxylate on the surface of FePt NPs. ${ }^{26,34,35}$ The absorption at $\sim 2540 \mathrm{~cm}^{-1}$ corresponding to the $\mathrm{S}-\mathrm{H}$ stretching vibration of Cys molecules (Figure 4H) disappeared in the FTIR spectra of the FePt-Cys NPs (Figure 4F and G), implying that Cys molecules were anchored on the surface of the FePt NPs through mercapto groups, with which Pt atoms have a high affinity. ${ }^{36}$

\section{Suppression of FePt NPs in glioma cell proliferation}

In order to evaluate the cytotoxicity of FePt NPs on glioma cells, three typical glioma cell lines (human glioma U251 cells, human astrocytoma $\mathrm{U} 87$ cells, and human neuroglioma $\mathrm{H} 4$ cells) were employed as in vitro models. Glioma cells were incubated with FePt NPs at designed doses and time intervals and cell viability was assessed by MTT assay. As shown in Figure 5, human glioma U251 cells were exposed to lipophilic FePt-OA/OA
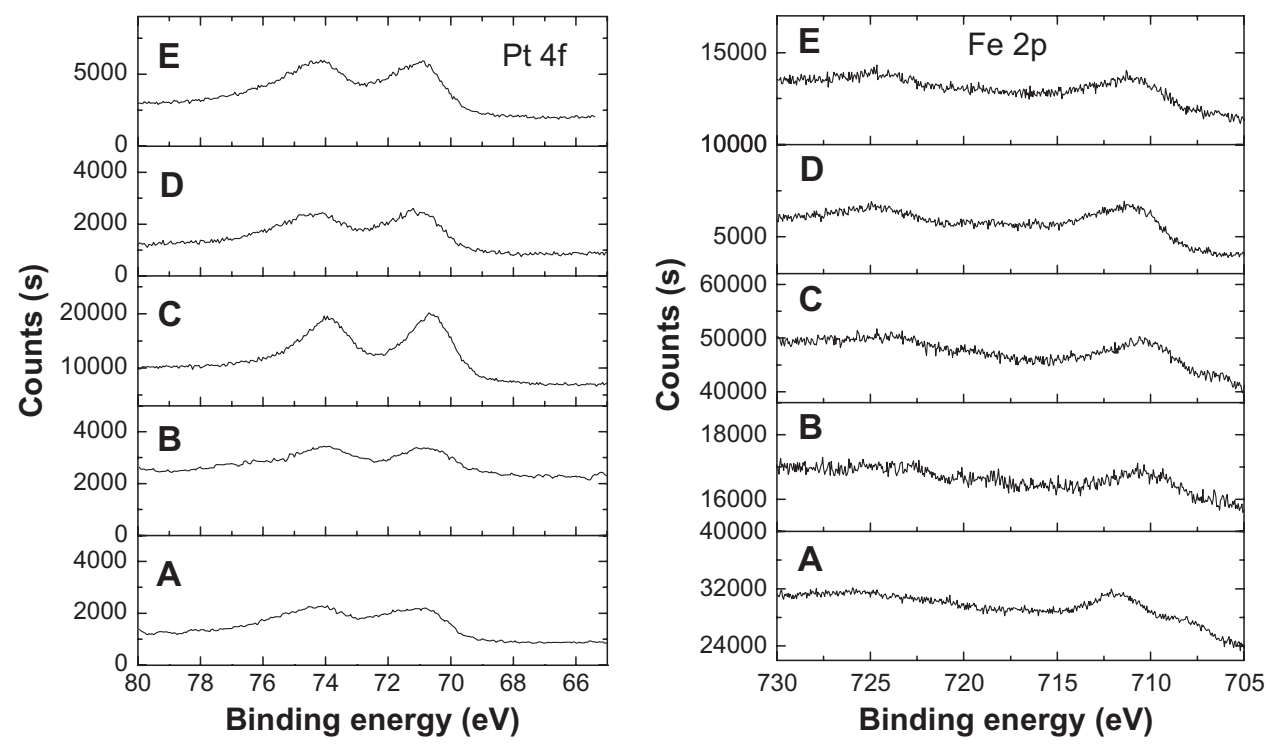

Figure 3 XPS spectra of $\mathrm{Pt}$ and Fe elements in the FePt NPs synthesized at different Fe/Pt molar ratios and with different surface coatings.

Notes: (A) $\mathrm{Fe}_{60} \mathrm{Pt}_{40}-\mathrm{OA} / \mathrm{OA}$; (B) $\mathrm{Fe}_{45} \mathrm{Pt}_{55}-\mathrm{OA} / \mathrm{OA}$; (C) $\mathrm{Fe}_{27} \mathrm{Pt}_{73}-\mathrm{OA} / \mathrm{OA}$; (D) $\mathrm{Fe}_{60} \mathrm{Pt}_{40}-\mathrm{Cys}$; (E) $\mathrm{Fe}_{24} \mathrm{Pt}_{76}-\mathrm{Cys}$.

Abbreviations: XPS, X-ray photon spectroscopy; OA/OA, oleic acid/oleylamine; Cys, cysteine. 

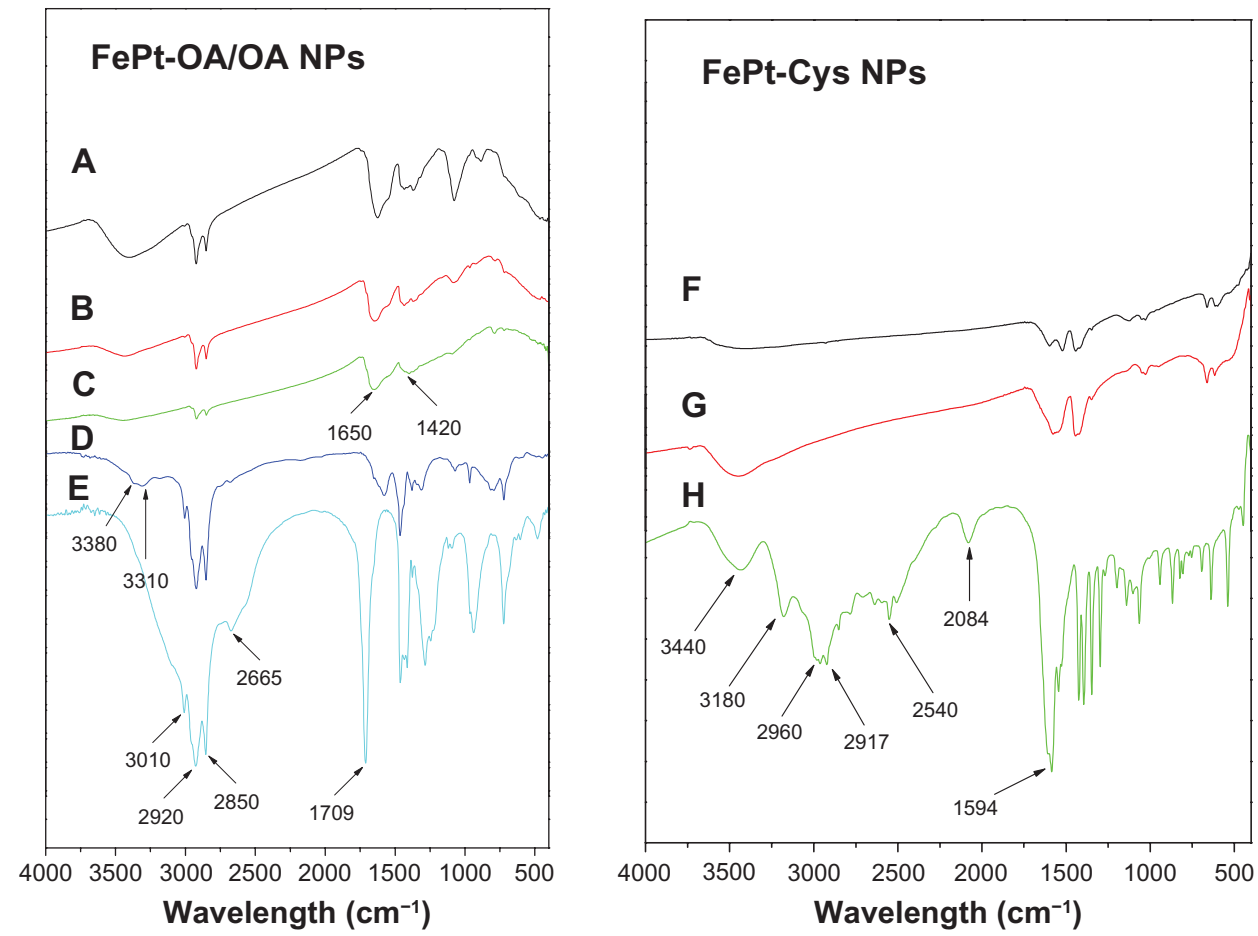

Figure 4 FTIR spectra of FePt NPs synthesized with different surface coatings and components.

Notes: (A) $\mathrm{Fe}_{60} \mathrm{Pt}_{40}$-OA/OA; (B) $\mathrm{Fe}_{45} \mathrm{Pt}_{55}-\mathrm{OA} / \mathrm{OA}$; (C) $\mathrm{Fe}_{27} \mathrm{Pt}_{73}-\mathrm{OA} / \mathrm{OA}$; (D) oleylamine; (E) oleic acid; (F) $\mathrm{Fe}_{60} \mathrm{Pt}_{40}-\mathrm{Cys}$; (G) $\mathrm{Fe}_{24} \mathrm{Pt}_{76}-\mathrm{Cys}$; (H) cysteine. Abbreviations: FTIR, Fourier transform infrared spectroscopy; NPs, nanoparticles; OA/OA, oleic acid/oleylamine.

NPs at doses ranging from 0.1 to $25 \mu \mathrm{g} / \mathrm{mL}$ for up to 48 hours and hydrophilic FePt-Cys NPs at doses ranging from 25 to $200 \mu \mathrm{g} / \mathrm{mL}$ for up to 72 hours. When U251 cells were treated with $\mathrm{Fe}_{60} \mathrm{Pt}_{40}-\mathrm{OA} / \mathrm{OA}$ NPs at a dose of $0.1 \mu \mathrm{g} / \mathrm{mL}$, cell proliferation was slightly decreased to approximately $88.6 \% \pm 3.4 \%$, $88.0 \% \pm 10.0 \%, 74.3 \% \pm 6.4 \%$, and $78.0 \% \pm 5.1 \%$ compared with that of the control group at incubation times of $6,12,24$, and 48 hours (Figure 5A). Increasing the exposed dose to $25 \mu \mathrm{g} / \mathrm{mL}$, cell proliferation was dramatically decreased to approximately $58.4 \% \pm 5.0 \%, 55.2 \% \pm 3.5 \%, 51.7 \% \pm 4.4 \%$, and $43.3 \% \pm 3.6 \%$ compared to that of the control group at the same incubation intervals. When U251 cells were treated with $\mathrm{Fe}_{60} \mathrm{Pt}_{40}-\mathrm{OA} / \mathrm{OA} \mathrm{NPs}$ at the exposed doses of 0.1, 1,5 , and $25 \mu \mathrm{g} / \mathrm{mL}$ for 6 hours, cell proliferation was sharply decreased to $88.6 \% \pm 3.4 \%, 78.6 \% \pm 6.2 \%, 60.8 \% \pm 9.0 \%$, and $58.4 \% \pm 5.0 \%$ compared to that of the control group. These results show that the proliferation of U251 cells was significantly suppressed by $\mathrm{Fe}_{60} \mathrm{Pt}_{40}-\mathrm{OA} / \mathrm{OA} \mathrm{NPs}$ in a timeand dose-dependent manner. Similarly, the proliferation of U251 cells was significantly suppressed by both $\mathrm{Fe}_{45} \mathrm{Pt}_{55}-\mathrm{OA} /$ OA NPs and $\mathrm{Fe}_{27} \mathrm{Pt}_{73}-\mathrm{OA} / \mathrm{OA}$ NPs in a dose-dependent manner (Figure 5B and C). It seems that the proliferation of U251 cells was more sensitive to changes in the doses than to changes in the incubation times in the case of both $\mathrm{Fe}_{45} \mathrm{Pt}_{55}-\mathrm{OA} / \mathrm{OA}$ NPs and $\mathrm{Fe}_{27} \mathrm{Pt}_{73}-\mathrm{OA} / \mathrm{OA} \mathrm{NPs}$, suggesting acute cytotoxic effects on U251 cells induced by these two FePt NPs. On the other hand, both $\mathrm{Fe}_{45} \mathrm{Pt}_{55}-\mathrm{OA} / \mathrm{OA} \mathrm{NPs}$ and $\mathrm{Fe}_{27} \mathrm{Pt}_{73}-\mathrm{OA} / \mathrm{OA} \mathrm{NPs}$ displayed slightly stronger cytotoxic effects on $\mathrm{U} 251$ cells than $\mathrm{Fe}_{60} \mathrm{Pt}_{40}-\mathrm{OA} / \mathrm{OA} \mathrm{NPs}$ under the same incubation conditions. For example, when U251 cells were incubated with FePt-OA/OA NPs for 12 hours at doses ranging from 0.1 to $25 \mu \mathrm{g} / \mathrm{mL}$, cell proliferation was decreased to approximately $88.0 \% \pm 10.0 \%$, $67.7 \% \pm 7.4 \%, 57.7 \% \pm 6.1 \%$, and $55.2 \% \pm 3.5 \%$ in the case of $\mathrm{Fe}_{60} \mathrm{Pt}_{40}-\mathrm{OA} / \mathrm{OA} \mathrm{NPs}$; approximately $67.5 \% \pm 11.1 \%$, $51.1 \% \pm 8.8 \%, 53.3 \% \pm 4.7 \%$, and $47.6 \% \pm 4.0 \%$ in the case of $\mathrm{Fe}_{45} \mathrm{Pt}_{55}-\mathrm{OA} / \mathrm{OA} \mathrm{NPs}$; and approximately $59.3 \% \pm 7.7 \%$, $52.9 \% \pm 3.8 \%, 47.2 \% \pm 5.0 \%$, and $46.7 \% \pm 8.2 \%$ in the case of $\mathrm{Fe}_{27} \mathrm{Pt}_{73}-\mathrm{OA} / \mathrm{OA}$ NPs. On the contrary, no or low cytotoxic effects were observed when U251 cells were incubated with hydrophilic FePt-Cys NPs at doses lower than $25 \mu \mathrm{g} / \mathrm{mL}$ for up to 48 hours (data not shown). Significant suppression of cell proliferation by FePt-Cys NPs was observed at exposed doses higher than $25 \mu \mathrm{g} / \mathrm{mL}$. As shown in Figure 5D and E, cell proliferation was significantly suppressed in a dose-dependent manner when the exposed doses ranged from $25 \mu \mathrm{g} / \mathrm{mL}$ to $200 \mu \mathrm{g} / \mathrm{mL}$. Therefore, these results indicate that the surface coatings of FePt NPs play a more crucial role in the suppression of U251 cell proliferation than their components.

The suppression of FePt NPs on glioma cell proliferation was further confirmed using human astrocytoma U87 cells 

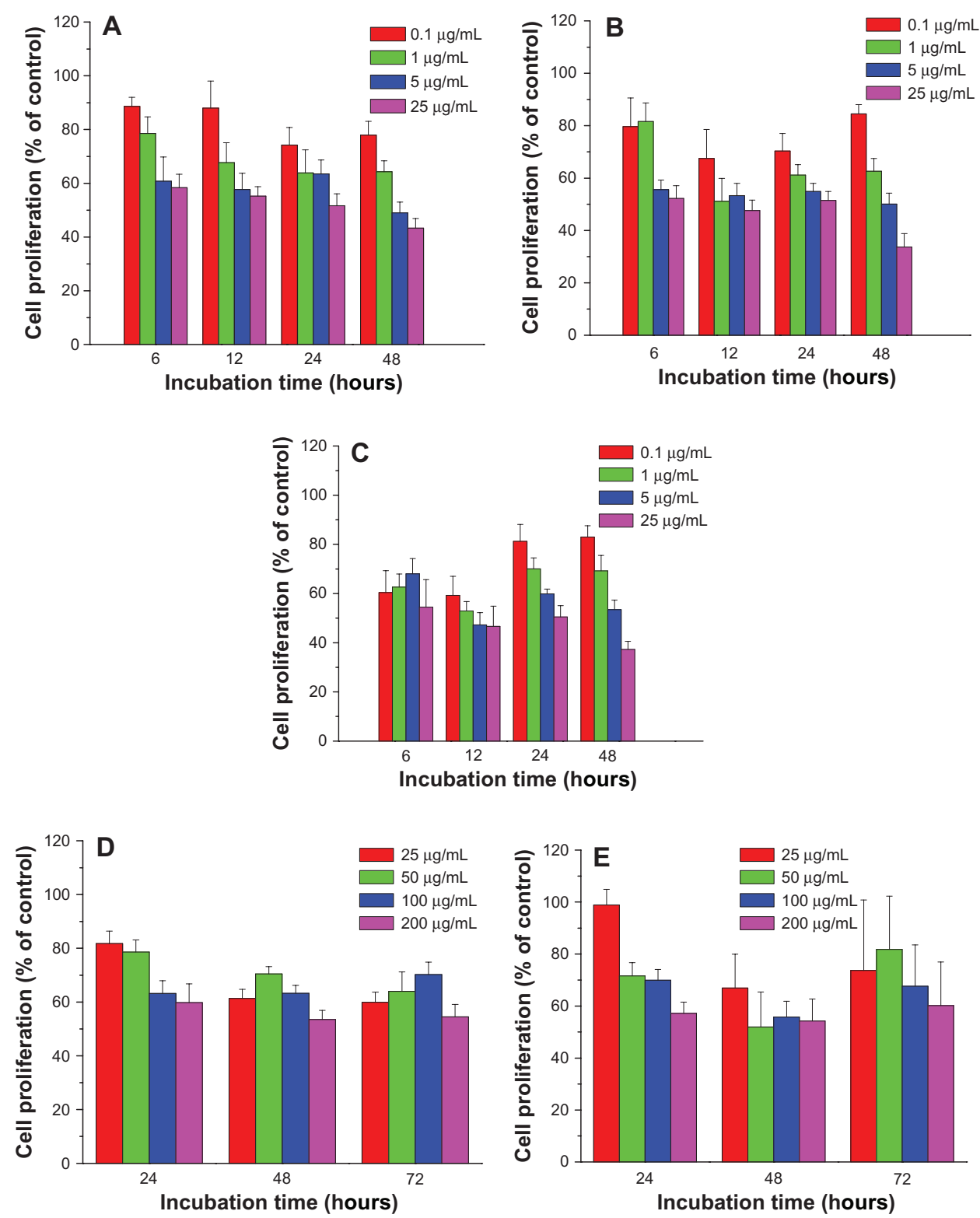

Figure 5 Cell proliferation of human glioma U25I cells treated with FePt NPs with different components and surface coatings. Notes: (A) $\mathrm{Fe}_{60} \mathrm{Pt}_{40}-\mathrm{OA} / \mathrm{OA}$; (B) $\mathrm{Fe}_{45} \mathrm{Pt}_{55} \mathrm{OA} / \mathrm{OA}$; (C) $\mathrm{Fe}_{27} \mathrm{Pt}_{73}-\mathrm{OA} / \mathrm{OA}$; (D) $\mathrm{Fe}_{60} \mathrm{Pt}_{40}-\mathrm{Cys}$; (E) $\mathrm{Fe}_{24} \mathrm{Pt}_{76}-{ }^{-C y s}$.

Abbreviations: NPs, nanoparticles; OA/OA, oleic acid/oleylamine; Cys, cysteine.

and human neuroglioma $\mathrm{H} 4$ cells as models. As shown in Figure 6, the proliferation of U87 cells was significantly suppressed by both $\mathrm{Fe}_{60} \mathrm{Pt}_{40}-\mathrm{OA} / \mathrm{OA} \mathrm{NPs}$ and $\mathrm{Fe}_{27} \mathrm{Pt}_{73}-\mathrm{OA} / \mathrm{OA}$ NPs in a time-dependent manner at exposed doses higher than $5 \mu \mathrm{g} / \mathrm{mL}$, while dose-dependent suppression on cell proliferation was observed after 12 hours' incubation. By comparison, $\mathrm{Fe}_{45} \mathrm{Pt}_{55}-\mathrm{OA} / \mathrm{OA}$ NPs induced a time-dependent suppression of $\mathrm{U} 87$ cell proliferation and seemed to be more toxic than the other two FePt-OA/OA NPs. For example, cell proliferation was decreased to approximately $72.8 \% \pm 5.4 \%$, $67.8 \% \pm 4.5 \%, 67.9 \% \pm 1.3 \%$, and $64.4 \% \pm 4.2 \%$ compared to that of the control group when cells were incubated with
$\mathrm{Fe}_{45} \mathrm{Pt}_{55}-\mathrm{OA} / \mathrm{OA}$ NPs for 6 hours at exposed doses from 0.1 to $25 \mu \mathrm{g} / \mathrm{mL}$. Under the same incubation conditions, cell proliferation decreased to approximately $81.2 \% \pm 9.7 \%$, $80.1 \% \pm 12.9 \%, 80.0 \% \pm 9.4 \%$, and $64.6 \% \pm 7.6 \%$ in the case of the $\mathrm{Fe}_{60} \mathrm{Pt}_{40}-\mathrm{OA} / \mathrm{OA} \mathrm{NPs}$, and approximately $86.3 \% \pm 5.7 \%$, $84.9 \% \pm 4.9 \%, 87.8 \% \pm 11.4 \%$ and $72.1 \% \pm 7.9 \%$ in the case of the $\mathrm{Fe}_{27} \mathrm{Pt}_{73}-\mathrm{OA} / \mathrm{OA}$ NPs.

Similarly, the proliferation of $\mathrm{H} 4$ cells was significantly suppressed by lipophilic FePt-OA/OA NPs in a time-dependent manner (Figure 7). Under the same incubation conditions, $\mathrm{Fe}_{45} \mathrm{Pt}_{55}-\mathrm{OA} / \mathrm{OA} \mathrm{NPs}$ were more toxic to $\mathrm{H} 4$ cells than the other two FePt-OA/OA NPs. For example, when 

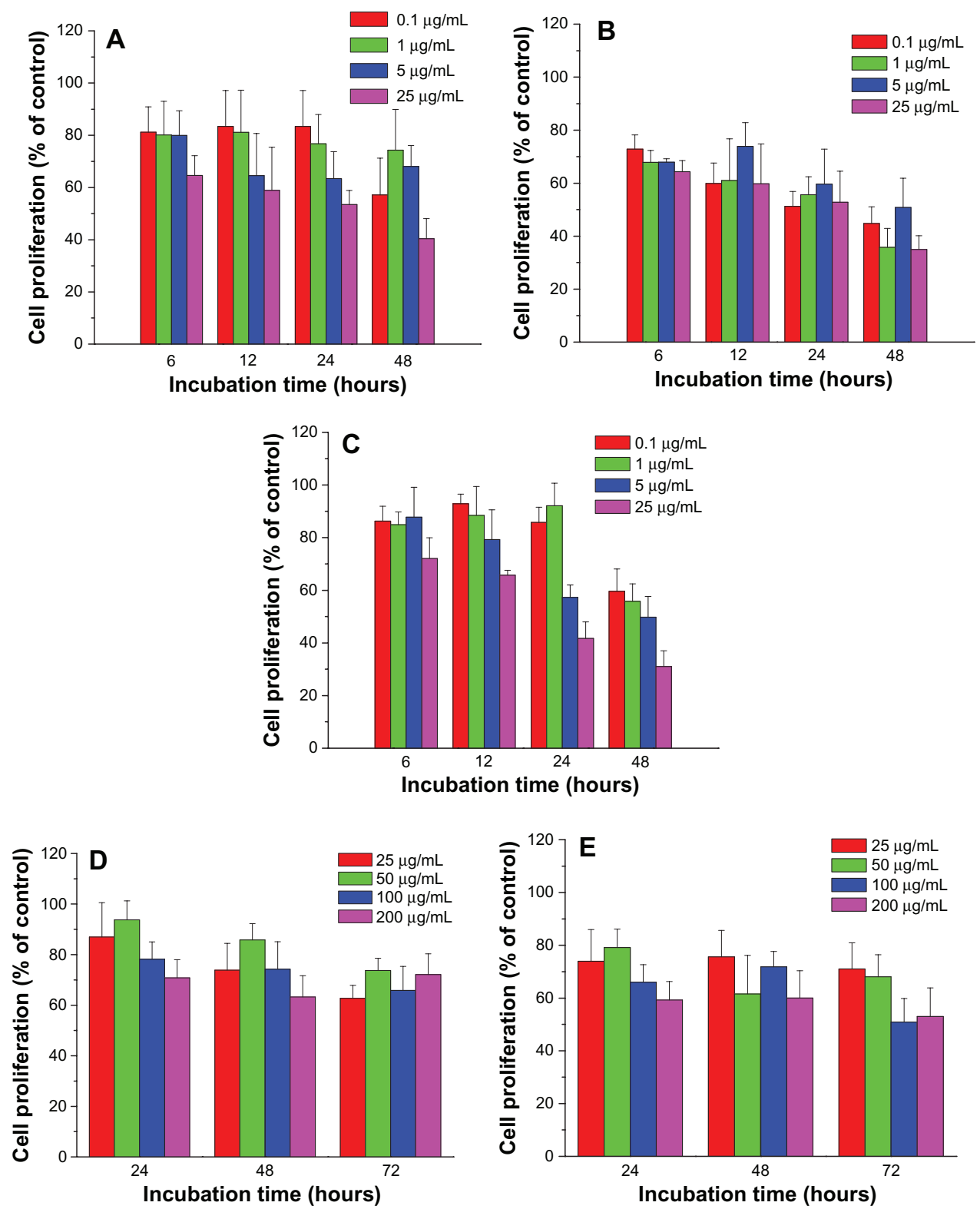

Figure 6 Cell proliferation of human astrocytoma U87 cells treated with FePt NPs with different components and surface coatings. Notes: (A) $\mathrm{Fe}_{60} \mathrm{Pt}_{40}-\mathrm{OA} / \mathrm{OA}$; (B) $\mathrm{Fe}_{45} \mathrm{Pt}_{55}-\mathrm{OA} / \mathrm{OA}$; (C) $\mathrm{Fe}_{27} \mathrm{Pt}_{73}-\mathrm{OA} / \mathrm{OA}$; (D) $\mathrm{Fe}_{60} \mathrm{Pt}_{40}-\mathrm{Cys}$; (E) $\mathrm{Fe}_{24} \mathrm{Pt}_{76}-\mathrm{Cys}$.

Abbreviations: NPs, nanoparticles; OA/OA, oleic acid/oleylamine; Cys, cysteine.

H4 cells were incubated with FePt-OA/OA NPs at different doses ranging from 0.1 to $25 \mu \mathrm{g} / \mathrm{mL}$ for 12 hours, cell proliferation was decreased to approximately $81.4 \% \pm 6.0 \%$, $65.3 \% \pm 16.1 \%, 72.8 \% \pm 16.1 \%$, and $72.6 \% \pm 12.1 \%$ in the case of $\mathrm{Fe}_{60} \mathrm{Pt}_{40}-\mathrm{OA} / \mathrm{OA} \mathrm{NPs}$; approximately $61.7 \% \pm 10.2 \%$, $73.1 \% \pm 10.7 \%, 56.0 \% \pm 8.6 \%$, and $50.6 \% \pm 4.0 \%$ in the case of $\mathrm{Fe}_{45} \mathrm{Pt}_{55}-\mathrm{OA} / \mathrm{OA} \mathrm{NPs}$; and approximately $92.5 \% \pm 8.3 \%$, $90.4 \% \pm 13.6 \%, 70.1 \% \pm 11.2 \%$, and $76.1 \% \pm 8.8 \%$ in the case of $\mathrm{Fe}_{27} \mathrm{Pt}_{73}-\mathrm{OA} / \mathrm{OA}$ NPs. On the other hand, the slight suppression on the proliferation of both U87 cells and $\mathrm{H} 4$ cells was induced by hydrophilic FePt-Cys NPs at the exposed dose of $25 \mu \mathrm{g} / \mathrm{mL}$ after 24 hours' incubation
(Figures 6D and E; Figures 7D and E). The remarkable decreases of cell viability were observed either at prolonged incubation times (up to 72 hours) or at higher exposed doses $(>100 \mu \mathrm{g} / \mathrm{mL})$. Therefore, these results demonstrated that the suppression of FePt NPs on glioma cell proliferation was dominantly determined by their surface coatings rather than their components.

\section{Cellular uptake of FePt NPs by glioma cells}

The cellular uptake of FePt NPs with different surface coatings and components by glioma cells was studied 

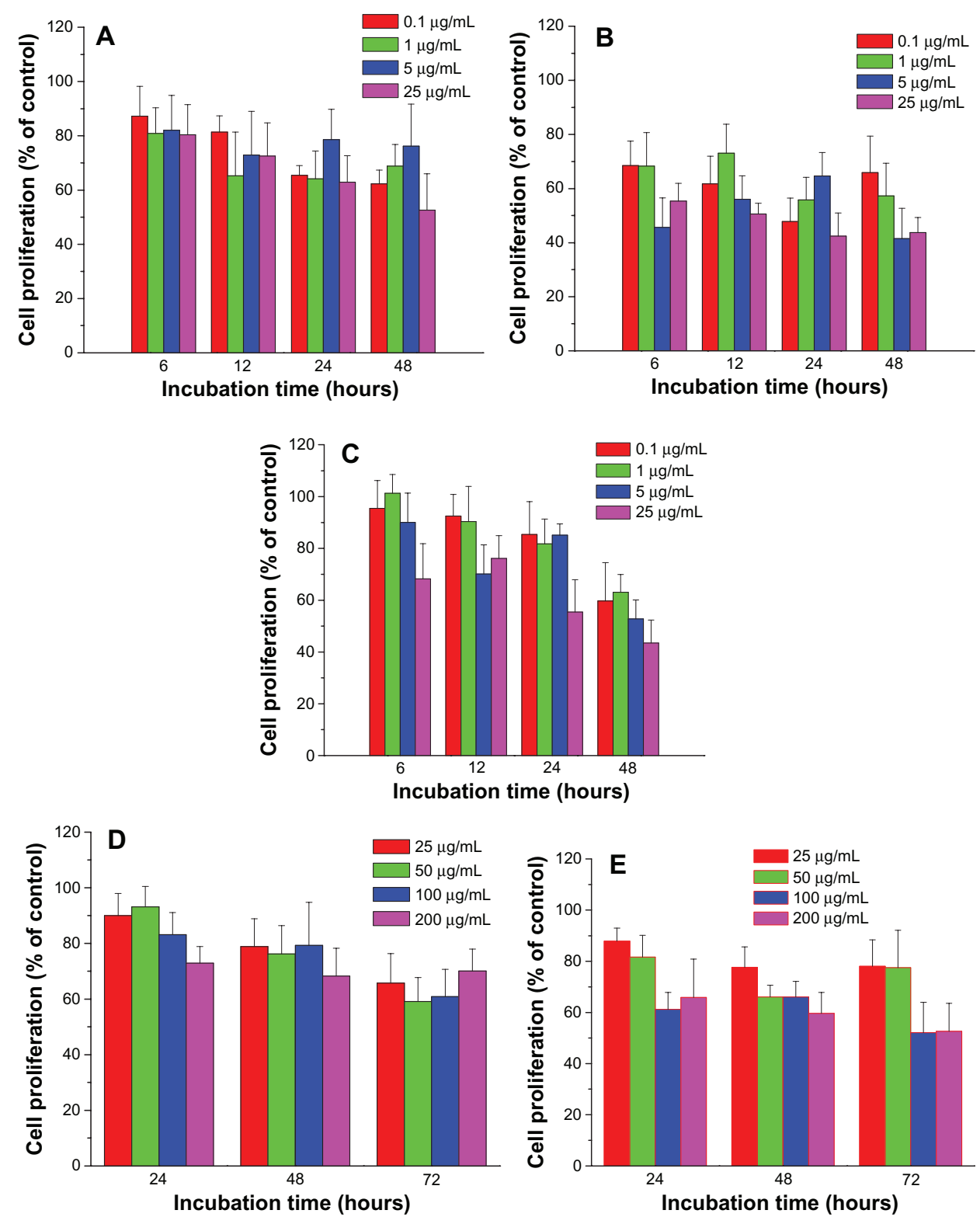

Figure 7 Cell proliferation of human neuroglioma $\mathrm{H} 4$ cells treated by FePt NPs with different components and surface coatings. Notes: (A) $\mathrm{Fe}_{60} \mathrm{Pt}_{40}-\mathrm{OA} / \mathrm{OA}$; (B) $\mathrm{Fe}_{45} \mathrm{Pt}_{55} \mathrm{OA} / \mathrm{OA}$; (C) $\mathrm{Fe}_{27} \mathrm{Pt}_{73}-\mathrm{OA} / \mathrm{OA}$; (D) $\mathrm{Fe}_{60} \mathrm{Pt}_{40}-\mathrm{Cys}$; (E) $\mathrm{Fe}_{24} \mathrm{Pt}_{76}-\mathrm{Cys}$.

Abbreviations: NPs, nanoparticles; OA/OA, oleic acid/oleylamine; Cys, cysteine.

using TEM. Glioma cells were incubated with FePt NPs at a dose of $25 \mu \mathrm{g} / \mathrm{mL}$ for 24 hours. As shown in Figure 8, numerous vesicles containing FePt NPs were visible in the interior space of the U251 cells, providing direct evidence for the internalization of FePt NPs. The insets in Figure $8 \mathrm{~A}$ and $\mathrm{B}$ show that the aggregates of FePt NPs contained in the vesicles were released and diffused into the cytoplasm. The initial phase involved the caveolae, and the formation of the vesicles enwrapping the aggregates of FePt NPs is shown in the inset of Figure 8E. Although the proliferation of U251 cells was significantly suppressed by FePt NPs dominantly dependent on their surface coatings, cellular uptake of FePt NPs by U251 cells seemed to be independent of both their surface coatings and components.

The internalizations of FePt NPs with different surface coatings and components were further confirmed by human astrocytoma U87 cells and human neuroglioma $\mathrm{H} 4$ cells, as shown in Figures 9 and 10. The adsorption of FePt NPs on the surface of cellular membranes is shown in Figure 9D (marked with a white arrow); the release and diffusion of FePt NPs from the vesicles into the cytoplasm are shown in Figures 9A, 10A and C (marked with white arrows); while Figure 9B shows that an aggregate of FePt NPs penetrated 

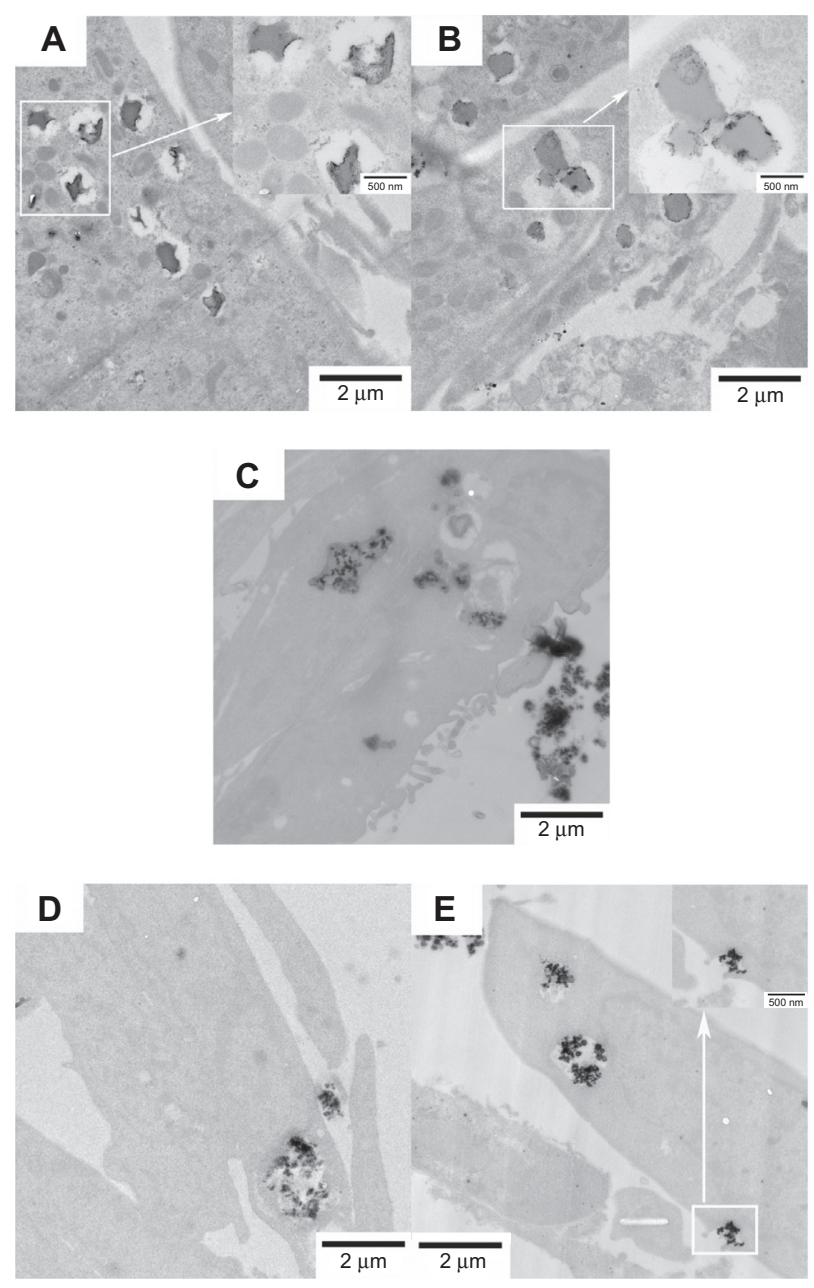

Figure 8 Representative TEM images showing the uptake of FePt NPs with different components and surface coatings by human glioma U25I cells at the exposed dose of $25 \mu \mathrm{g} / \mathrm{mL}$ after 24 hours' incubation.

Notes: (A) $\mathrm{Fe}_{60} \mathrm{Pt}_{40}-\mathrm{OA} / \mathrm{OA}$; (B) $\mathrm{Fe}_{45} \mathrm{Pt}_{55}-\mathrm{OA} / \mathrm{OA}$; (C) $\mathrm{Fe}_{27} \mathrm{Pt}_{73}-\mathrm{OA} / \mathrm{OA}$; (D) $\mathrm{Fe}_{60} \mathrm{Pt}_{40}{ }^{-}$ Cys; (E) $\mathrm{Fe}_{24} \mathrm{Pt}_{76}$-Cys. Numerous vesicles containing the aggregative FePt NPs were visible intracellularly and were dispersed randomly in the cytoplasm. The insets in panels ( $\mathbf{A}$ and $\mathbf{B})$ are enlargements of the areas marked in white, showing the aggregative FePt NPs contained in the vesicles. The inset in panel $(\mathbf{E})$ is the enlargement of the area marked in white, showing the formation of a vesicle containing an aggregate of FePt NPs.

Abbreviations: TEM, transmission electron microscopy; NPs, nanoparticles; OA/ OA, oleic acid/oleylamine; Cys, cysteine.

through the nuclear membrane into the cell nucleus (marked with a white arrow).

\section{Zeta potential of FePt NPs}

The zeta potential of the FePt NPs was measured in phosphate buffer solution and cell culture medium, respectively. When the FePt NPs were dispersed in phosphate buffer solution with a $\mathrm{pH}$ value of $\sim 7.4$, the measured zeta potential was approximately $-20.5 \pm 6.2,-12.9 \pm 1.4$, and $-9.0 \pm 3.0 \mathrm{mV}$ corresponding to lipophilic $\mathrm{Fe}_{60} \mathrm{Pt}_{40}-\mathrm{OA} / \mathrm{OA}, \mathrm{Fe}_{45} \mathrm{Pt}_{55}-\mathrm{OA} / \mathrm{OA}$, and $\mathrm{Fe}_{27} \mathrm{Pt}_{73}-\mathrm{OA} /$ OA NPs, respectively, which was much higher than that of hydrophilic $\mathrm{Fe}_{60} \mathrm{Pt}_{40}$-Cys NPs (approximately $-42.5 \pm 4.1 \mathrm{mV}$ )
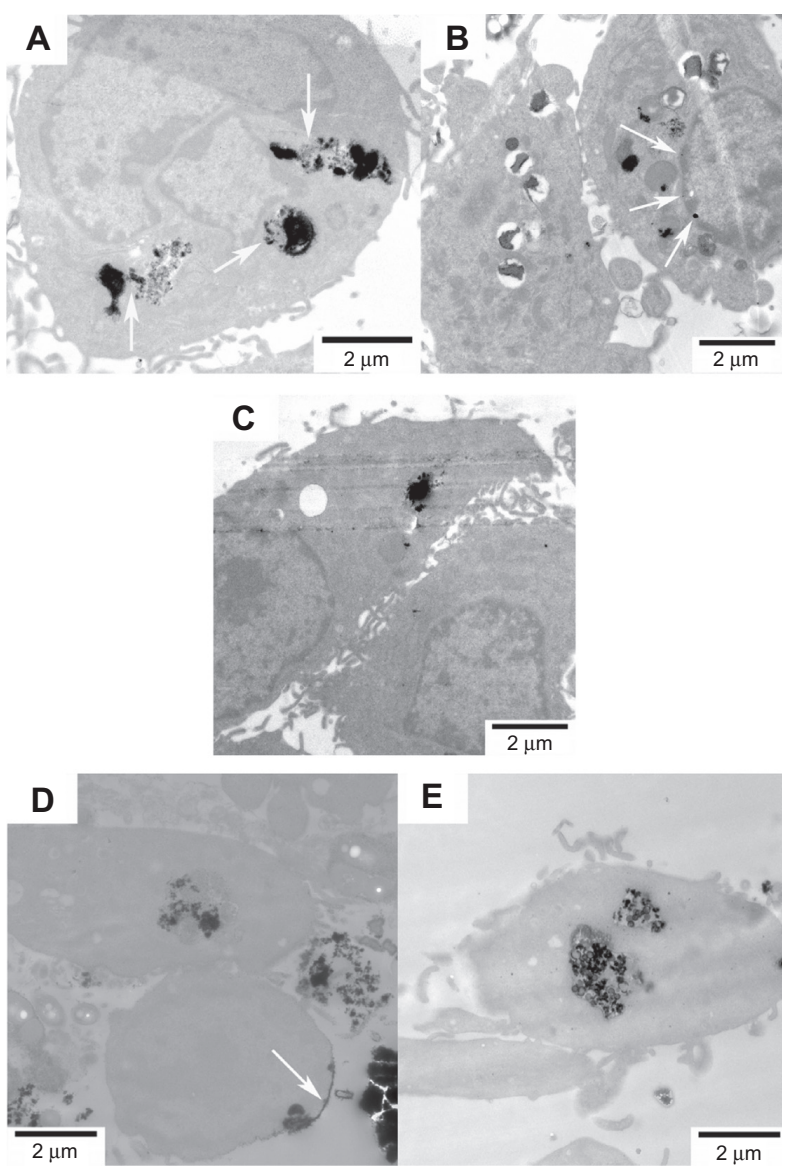

Figure 9 Representative TEM images showing the uptake of FePt NPs with different components and surface coatings by human astrocytoma U87 cells at the exposed dose of $25 \mu \mathrm{g} / \mathrm{mL}$ after 24 hours' incubation.

Notes: (A) $\mathrm{Fe}_{60} \mathrm{Pt}_{40}-\mathrm{OA} / \mathrm{OA}$; (B) $\mathrm{Fe}_{45} \mathrm{Pt}_{55}-\mathrm{OA} / \mathrm{OA}$; (C) $\mathrm{Fe}_{27} \mathrm{Pt}_{73}-\mathrm{OA} / \mathrm{OA}$; (D) $\mathrm{Fe}_{60} \mathrm{Pt}_{40}{ }^{-}$ Cys; (E) $\mathrm{Fe}_{24} \mathrm{Pt}_{76}-$ Cys. The release and diffusion of FePt NPs from the vesicles into the cytoplasm were observed and are marked with white arrows in panel $(\mathbf{A})$; the penetration of FePt NPs through the nuclear membrane was shown and is marked with white arrows in panel (B). The adsorption of FePt NPs on the surface of cellular membrane was shown and is marked with a white arrow in panel (D).

Abbreviations: TEM, transmission electron microscopy; NPs, nanoparticles; OA/ OA, oleic acid/oleylamine; Cys, cysteine.

and $\mathrm{Fe}_{24} \mathrm{Pt}_{76}$-Cys NPs $(-22.8 \pm 3.2 \mathrm{mV})$. The differences in zeta potential could be attributed to different functional groups contained in the surface coating molecules. Each oleic acid and oleylamine molecule only contains one carboxyl group $(-\mathrm{COOH})$ and one amine group $\left(-\mathrm{NH}_{2}\right)$, which was consumed for adsorbing on the surface of FePt NPs, while each Cys molecule contains one carboxyl group $(-\mathrm{COOH})$, one mercapto group (-SH), and one amine group $\left(-\mathrm{NH}_{2}\right)$. This means that at least one of the negatively charged groups $(-\mathrm{COOH}$ or $-\mathrm{SH})$ was free after the adsorption of Cys molecules on FePt NPs. Subsequently, when FePt NPs were dispersed in cell culture medium with a $\mathrm{pH}$ value of $\sim 7.25$, the zeta potentials of lipophilic $\mathrm{Fe}_{60} \mathrm{Pt}_{40}-\mathrm{OA} / \mathrm{OA}, \mathrm{Fe}_{45} \mathrm{Pt}_{55}-\mathrm{OA} /$ $\mathrm{OA}$ and $\mathrm{Fe}_{27} \mathrm{Pt}_{73}-\mathrm{OA} / \mathrm{OA}$ NPs were dramatically increased to approximately $-6.4 \pm 1.6,-8.6 \pm 1.0$, and $-3.6 \pm 1.5 \mathrm{mV}$, 

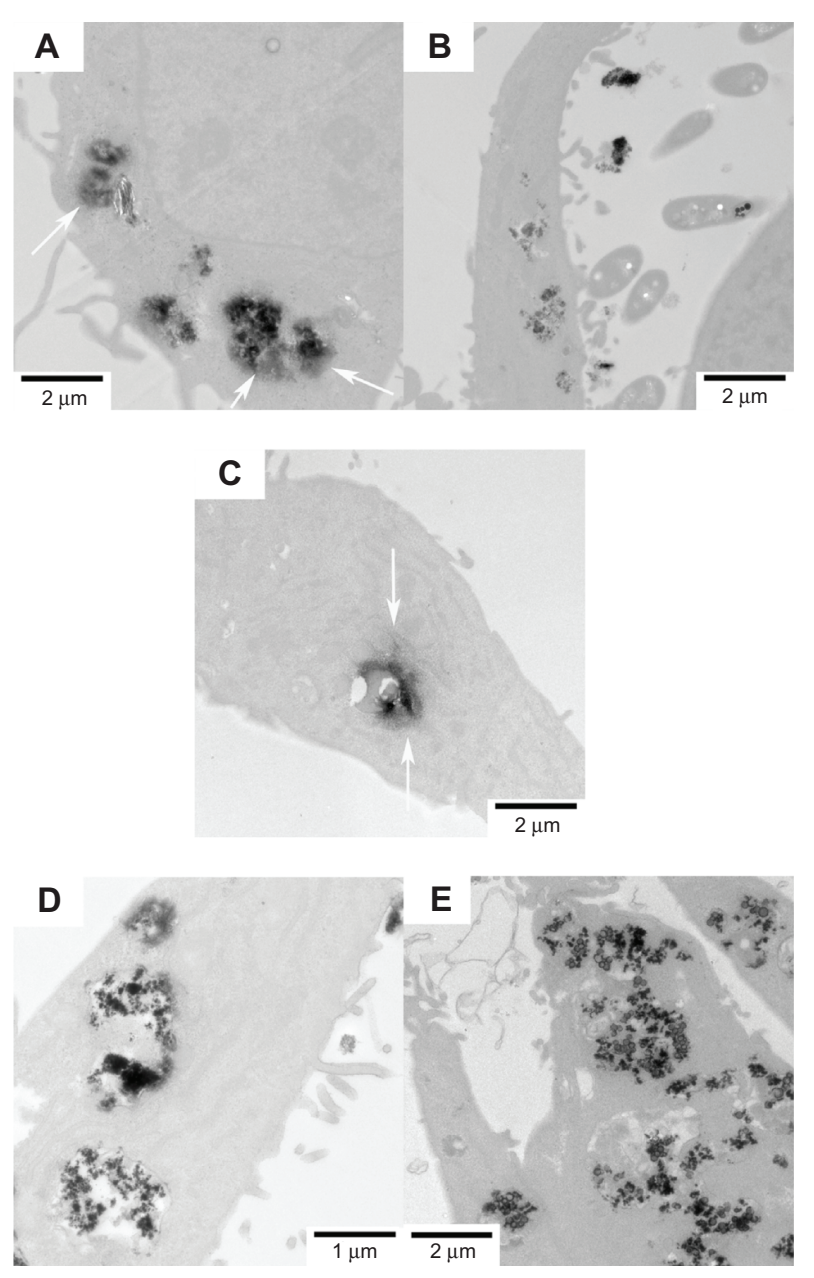

Figure 10 Representative TEM images showing the uptake of FePt NPs with different components and surface coatings by human neuroglioma $\mathrm{H} 4$ cells at the exposed dose of $25 \mu \mathrm{g} / \mathrm{mL}$ after 24 hours' incubation.

Notes: (A) $\mathrm{Fe}_{60} \mathrm{Pt}_{40}-\mathrm{OA} / \mathrm{OA}$; (B) $\mathrm{Fe}_{45} \mathrm{Pt}_{55}-\mathrm{OA} / \mathrm{OA}$; (C) $\mathrm{Fe}_{27} \mathrm{Pt}_{73}-\mathrm{OA} / \mathrm{OA}$; (D) $\mathrm{Fe}_{60} \mathrm{Pt}_{40}{ }^{-}$ Cys; (E) $\mathrm{Fe}_{24} \mathrm{Pt}_{76}$-Cys. The release and diffusion of FePt NPs from the vesicles into the cytoplasm were observed and are marked with white arrows in panels ( $\mathbf{A}$ and $\mathbf{B}$ ). Abbreviations: TEM, transmission electron microscopy; NPs, nanoparticles; OA/ OA, oleic acid/oleylamine; Cys, cysteine.

respectively, and those of hydrophilic $\mathrm{Fe}_{60} \mathrm{Pt}_{40}-\mathrm{Cys}$ and $\mathrm{Fe}_{24} \mathrm{Pt}_{76}-$ Cys NPs were increased to approximately $-16.3 \pm 3.0 \mathrm{mV}$ and $-12.1 \pm 1.6 \mathrm{mV}$. The dramatic increases of zeta potential in cell culture medium could be attributed to different ionic strengths, the presence of proteins, and other factors in culture media. Therefore, the negative zeta potential of FePt NPs confirms that few aggregates of FePt NPs could be attributed to the repulsive forces of the negatively charged surfaces of FePt NPs.

\section{Discussion}

It has been reported that both $\mathrm{FePt} @ \mathrm{CoS}_{2}$ and $\mathrm{FePt} @ \mathrm{Fe}_{2} \mathrm{O}_{3}$ yolk-shell NPs significantly suppress the proliferation of HeLa cells with the $\mathrm{IC}_{50}$ value of approximately $35.5 \pm 4.7$ and $238 \pm 9 \mathrm{ng}$ of $\mathrm{Pt} / \mathrm{mL}$, which is much lower or approximate to that of cisplatin (230 $\mathrm{ng}$ of $\mathrm{Pt} / \mathrm{mL}) .{ }^{19,23}$ Additionally,
FePt NPs coated with a phospholipid bilayer or polymer shell have been shown to suppress the proliferation of various tumor cells (such as A2780, A431, Sk-Br3, and HEK-293) and induce a proinflammatory response on monocyte-derived macrophages and monocyte-derived dendritic cells. ${ }^{24,37}$ In the present study, monodispersed FePt NPs were tunably synthesized with different surface coatings and components. The potential application of FePt NPs for malignant glioma therapy was evaluated in vitro using three typical brain glioma cell lines (human glioma U251 cells, human astrocytoma U87 cells, and human neuroglioma H4 cells) as models. The results demonstrated that the proliferation of glioma cells was significantly suppressed by lipophilic FePt-OA/OA NPs in a time- and/or dose-dependent manner. The suppression of the proliferation of glioma cells was dominantly determined by their surface coatings rather than their components. Among these samples, $\mathrm{Fe}_{45} \mathrm{Pt}_{55}-\mathrm{OA} / \mathrm{OA}$ NPs displayed the greatest suppression of the proliferation of the three glioma cell lines under the same incubation conditions. The $\mathrm{IC}_{50}$ value of $\mathrm{Fe}_{45} \mathrm{Pt}_{55}-\mathrm{OA} / \mathrm{OA} \mathrm{NPs}$ in the three glioma cell lines was approximately $5-10 \mu \mathrm{g} / \mathrm{mL}$ after 24 hours' incubation. Therefore, these results demonstrate that, by engineering the surface coating, FePt NPs could be utilized as a novel and promising therapeutic nanomedicine for malignant gliomas.

In order to investigate the interactions between FePt NPs and glioma cells, the cellular uptake of FePt NPs was observed by TEM. Generally, cellular uptake of the NPs by the cells has been associated with the size, shape, and surface properties of the NPs. ${ }^{38-41}$ For example, gold and silver NPs coated with antibodies have been demonstrated to regulate membrane receptor-mediated internalization. ${ }^{39}$ The cellular uptake of gold nanostructures has been shown to be influenced by their size and shape, while their dependency on the factors could be varied by engineering the surface coatings. ${ }^{40}$ In this study, the cellular uptake of FePt NPs with different surface coatings and components was confirmed in different glioma cell lines. The zeta potential of FePt NPs was remarkably increased in cell culture medium, which decreased the repulsive force between negatively charged FePt NPs and the cell membrane and promoted the adsorption of FePt NPs on the cell membrane. The cellular uptake of FePt NPs by glioma cells may involve the adsorption of FePt NPs on the cell membrane (Figures 8C, D, 9D, and 10D), the caveolae (inset of Figure 8E) and the formation of the vesicles containing the aggregates of FePt NPs, and the release of FePt NPs from the vesicles and their diffusion into cytoplasm (Figures 9A, 10A, $\mathrm{C}$, and D) and various organelles. It is very interesting that 
the cellular uptake of FePt NPs was independent of their surface coatings and components. Recent work suggests that, in the absence of particle aggregation, cellular uptake of gold NPs is dependent on the ratio of sedimentation to diffusion velocities while independent of size, shape, density, surface coating, and initial concentration. ${ }^{42}$ Further investigation into the precise uptake mechanisms of FePt NPs by glioma cells are currently in progress.

The major cytotoxicities of inorganic NPs on tumor cells were attributed to the intracellular degradation of NPs, the subsequent release of toxic metal ions and the enhancement of intracellular reactive oxygen species levels. ${ }^{43-46}$ The excessive oxidative stress triggered a series of oxidative damages to cellular organelles and finally induced cell apoptosis and necrosis. The cytotoxic mechanisms of FePt NPs on glioma cells were still amphibolous. In previous studies, Gao et al ${ }^{19,23}$ suggest that FePt cores contained in FePt@ $\mathrm{CoS}_{2}$ and FePt@ $\mathrm{Fe}_{2} \mathrm{O}_{3}$ yolk-shell NPs were oxidized and disintegrated under intracellular acidic environments. Subsequently, the released $\mathrm{Pt}^{2+}$ ions diffused out of the shells and entered into the nucleus and mitochondria. The coordination between $\mathrm{Pt}^{2+}$ ions and 5'-GG-3' bases of DNA finally resulted in damage to DNA and the apoptosis of HeLa cells. However, Sun et al ${ }^{24}$ indicate that FePt NPs coated with phospholipid bilayers are etched in low $\mathrm{pH}$ solution $(\mathrm{pH}=4.8)$, which results in the controlled release of $\mathrm{Fe}$ ions but without the detectable release of $\mathrm{Pt}^{2+}$ ions. Fe ion-induced enhancement of intracellular reactive oxygen species levels initiates a series of oxidative damages and cell apoptosis. In this study, FePt NPs significantly suppressed the proliferation of glioma cells dominantly dependent on their surface coatings rather than their components. Although the zeta potentials of the FePt NPs were dependent on their surface coatings, the cellular uptake of FePt NPs was confirmed regardless of the surface the coatings and components. Therefore, we speculate that the surface coatings play a crucial role in the intracellular disintegration of FePt NPs. For example, the high affinity between the mercapto group of Cys molecules and $\mathrm{Pt} / \mathrm{Pt}^{2+}$ may play a crucial role in the intracellular disintegration of FePt NPs and DNA damage. Further investigation into the relationship between the surface coatings of FePt NPs and their intracellular disintegration are to be carried out by our group; these studies will be of great benefit to the elucidation of the primary cytotoxic mechanisms of FePt NPs in glioma cells.

\section{Conclusion}

We reported the tunable synthesis of monodispersed FePt NPs with different surface coatings and components and their characterization through XRD, TEM, XPS, FT-IR, AAS, and zeta potential. The potential application of FePt NPs for malignant glioma therapy was evaluated using three typical glioma cell lines (human glioma U251 cells, human astrocytoma U87 cells, and human neuroglioma H4 cells) as in vitro models. The results indicated that the proliferation of glioma cells was significantly suppressed by lipophilic FePt-OA/OA NPs instead of hydrophilic FePt-Cys NPs in a time- and/or dose-dependent manner. Although the cellular uptake of FePt NPs was confirmed by TEM observation regardless of the surface coatings and components of the FePt NPs, the suppression of FePt NPs on the proliferation of glioma cells was dominantly determined by their surface coatings rather than their components. The different surface coatings of FePt NPs were shown to impart different surface charges in both phosphate buffered saline and cell culture medium. These results suggest attractive potential for the use of FePt NPs in novel nanomedicines for malignant glioma therapy.

\section{Acknowledgments}

This work was financially supported by the Natural Science Foundation of China (No 30800256) and the Major Program of National Natural Science Foundation of China (No 81190133), the Research Fund for the Doctoral Program of Higher Education of China (No 200804971065), the Natural Science Foundation of Hubei Province of China (No 2008CDB035), the Self-Determined and Innovative Research Funds of WUT (No 2010la012), and the Program for Changjiang Scholars and Innovative Research Team in University (No IRT1169) at Wuhan University of Technology.

\section{Disclosure}

The authors report no conflicts of interest in this work.

\section{References}

1. Barbu E, Molnàr E, Tsibouklis J, Górecki DC. The potential for nanoparticle-based drug delivery to the brain: overcoming the bloodbrain barrier. Expert Opin Drug Deliv. 2009;6:553-565.

2. Pardridge WM. Drug and gene delivery to the brain: the vascular route. Neuron. 2002;36:555-558.

3. Juillerat-Jeanneret L. The targeted delivery of cancer drugs across the blood-brain barrier: chemical modifications of drugs or drugnanoparticles? Drug Discov Today. 2008;13:1099-1106.

4. Ferrari M. Cancer nanotechnology: opportunities and challenges. Nat Rev Cancer. 2005;5:161-171.

5. Riehemann K, Schneider SW, Luger TA, Godin B, Ferrari M, Fuchs H. Nanomedicine - challenge and perspectives. Angew Chem Int Ed Engl. 2009;48:872-897.

6. Koo YL, Reddy GR, Bhojani M, et al. Brain cancer diagnosis and therapy with nanoplatforms. Adv Drug Deliv Rev. 2006;58:1556-1577.

7. Cabada TF, de Pablo CS, Serrano AM, Guerrero Fdel P, Olmedo JJ, Gomez MR. Induction of cell death in a glioblastoma line by hyperthermic therapy based on gold nanorods. Int J Nanomed. 2012;7:1511-1523. 
8. Chertok B, David AE, Yang VC. Polyethyleneimine-modified iron oxide nanoparticles for brain tumor drug delivery using magnetic targeting and intra-carotid administration. Biomaterials. 2010;31:6317-6324.

9. Veiseh O, Sun C, Gunn J, et al. Optical and MRI multifunctional nanoprobe for targeting gliomas. Nano Lett. 2005;5:1003-1008.

10. Silva AC, Oliveira TR, Mamani JB, et al. Application of hyperthermia induced by superparamagnetic iron oxide nanoparticles in glioma treatment. Int J Nanomed. 2011;6:591-603.

11. Wang ST, Chen KJ, Wu TH, et al. Photothermal effects of supramolecularly assembled gold nanoparticles for the targeted treatment of cancer cells. Angew Chem Int Ed Engl. 2010;49:3777-3781.

12. Rozhkova EA, Ulasov I, Lai B, Dimitrijevic NM, Lesniak MS, Rajh T. A high-performance nanobio photocatalyst for targeted brain cancer therapy. Nano Lett. 2009;9:3337-3342.

13. Gao JH, Gu HW, Xu B. Multifunctional magnetic nanoparticles: design, synthesis, and biomedical applications. Acc Chem Res. 2009;42:1097-1107.

14. Gu HW, Ho P, Tsang KWT, Yu CW, Xu B. Using biofunctional magnetic nanoparticles to capture gram-negative bacteria at an ultra-low concentration. Chem Commun. 2003;15:1966-1967.

15. Gu HW, Ho P, Tsang KW, Wang L, Xu B. Using biofunctional magnetic nanoparticles to capture vancomycin-resistant enterococci and other gram-positive bacteria at ultralow concentration. JAm Chem Soc. 2003;125:15702-15703

16. $\mathrm{Xu} \mathrm{C}, \mathrm{Xu} \mathrm{K}, \mathrm{Gu} \mathrm{H}$, et al. Nitrilotriacetic acid-modified magnetic nanoparticles as a general agent to bind histidine-tagged proteins. J Am Chem Soc. 2004;126:3392-3393.

17. Hong R, Fischer NO, Emrick T, Rotello VM. Surface PEGylation and ligand exchange chemistry of FePt nanoparticles for biological applications. Chem Mater. 2005;17:4617-4621.

18. Chiang PC, Hung DS, Wang JW, Ho CS, Yao YD. Engineering waterdispersible FePt nanoparticles for biomedical applications. IEEE Trans Magn. 2007;43:2445-2447.

19. Gao J, Liang G, Cheung JS, et al. Multifunctional yolk-shell nanoparticles: a potential MRI contrast and anticancer agent. J Am Chem Soc. 2008;130:11828-11833.

20. Chen S, Wang LJ, Duce SL, et al. Engineering biocompatible nanoparticles for in vivo imaging applications. $\mathrm{J} \mathrm{Am} \mathrm{Chem} \mathrm{Soc}$ 2010;132:15022-15029.

21. Chou SW, Shau YH, Wu PC, Yang YS, Shieh DB, Chen CC. In vitro and in vivo studies of FePt nanoparticles for dual modal CT/MRI molecular imaging. J Am Chem Soc. 2010;132:13270-13278.

22. Yang H, Zhang JJ, Tian QW, et al. One-pot synthesis of amphiphilic superparamagnetic FePt nanoparticles and magnetic resonance imaging in vitro. J Magn Magn Mater. 2010;322:973-977.

23. Gao J, Liang L, Zhang B, Kuang Y, Zhang X, Xu B. FePt@CoS yolkshell nanocrystals as a potent agent to kill HeLa cells. J Am Chem Soc. 2007;129:1428-1433.

24. Xu C, Yuan Z, Kohler N, Kim J, Chung MA, Sun S. FePt nanoparticles as an Fe reservoir for controlled Fe release and tumor inhibition. $J \mathrm{Am}$ Chem Soc. 2009;131:15346-15351.

25. Elkins KE, Vedantam TS, Liu JP, et al. Ultrafine FePt nanoparticles prepared by the chemical reduction method. Nano Lett. 2003;3: 1647-1649.

26. Saita S, Maenosono S. Formation mechanism of FePt nanoparticles synthesized via pyrolysis of iron (III) ethoxide and platinum (II) acetylacetonate. Chem Mater. 2005;17:6624-6634.

International Journal of Nanomedicine

\section{Publish your work in this journal}

The International Journal of Nanomedicine is an international, peerreviewed journal focusing on the application of nanotechnology in diagnostics, therapeutics, and drug delivery systems throughout the biomedical field. This journal is indexed on PubMed Central, MedLine, CAS, SciSearch $₫$, Current Contents ${ }^{\circledR} /$ Clinical Medicine,
27. Teng X, Yang H. Synthesis of magnetic nanocomposites and alloys from platinum-iron oxide core-shell nanoparticles. Nanotechnology. 2005;16:S554-S561.

28. Loc Nguyen H, Howard LEM, Stinton GW, et al. Synthesis of size-Controlled fcc and fet FePt nanoparticles. Chem Mater. 2006;18:6414-6424.

29. Monnier V, Delalande M, Bayle Guillemaud P, Samson Y, Reiss P. Synthesis of homogeneous FePt nanoparticles using a nitrile ligand. Small. 2008;4:1139-1142.

30. Srivastava C, Balasubramanian J, Turner CH, Wiest JM, Bagaria HG, Thompson GB. Formation mechanism and composition distribution of FePt nanoparticles. J Appl Phys. 2007;102:104310-1-104310-8.

31. Stahl B, Gajbhiye NS, Wilde G, et al. Electronic and magnetic properties of monodispersed FePt nanoparticles. Adv Mater. 2002;14:24-27.

32. Sun S, Anders S, Thomson T, et al. Controlled synthesis and assembly of FePt nanoparticles. J Phys Chem B. 2003;107:5419-5425.

33. Suda M, Nakagawa M, Lyoda T, Einaga Y. Reversible photoswitching of ferromagnetic FePt nanoparticles at room temperature. $J \mathrm{Am}$ Chem Soc. 2007;129:5538-5543.

34. Salgueiriño-Maceira V, Liz-Marzán LM, Farle M. Water-based ferrofluids from $\mathrm{Fe}_{\mathrm{x}} \mathrm{Pt}_{1-\mathrm{x}}$ nanoparticles synthesized in organic media. Langmuir. 2004;20:6946-6950.

35. Lai CW, Wang YH, Uttam BP, et al. One-pot solvothermal synthesis of $\mathrm{FePt} / \mathrm{Fe}_{3} \mathrm{O}_{4}$ core-shell nanoparticles. Chem Commun (Camb). 2008;14:5342-5344.

36. Wu Q, Cao H, Luan Q, et al. Biomolecule-assisted synthesis of watersoluble silver nanoparticles and their biomedical applications. Inorg Chem. 2008;47:5882-5888.

37. Lehmann AD, Parak SJ, Zhang F, et al. Fluorescent-magnetic hybrid nanoparticles induce a dose-dependent increase in proinflammary response in lung cells in vitro correlated with intracellular localization. Small. 2010;6:753-762.

38. Verma A, Stellacci F. Effect of surface properties on nanoparticle-cell Iinteractions. Small. 2010;6:12-21.

39. Jiang W, Kim BY, Rutka JT, Chan WC. Nanoparticle-mediated cellular response is size-dependent. Nat Nanotechnol. 2008;3:145-150.

40. Cho EC, Au L, Zhang Q, Xia Y. The effects of size, shape, and surface functional group of gold nanostructures on their adsorption and internalization by cells. Small. 2010;6:517-522.

41. Verma A, Uzun O, Hu Y, et al. Surface-structure-regulated cellmembrane penetration by monolayer-protected nanoparticles. Nat Mater. 2008;7:588-595.

42. Cho EC, Zhang Q, Xia Y. The effect of sedimentation and diffusion on cellular uptake of gold nanoparticles. Nat Nanotechnol. 2011 6:385-391.

43. Lewinski N, Colvin V, Drezek R. Cytotoxicity of nanoparticles. Small. 2008;4:26-49.

44. Bhabra G, Sood A, Fisher B, et al. Nanoparticles can cause DNA damage across a cellular barrier. Nat Nanotechnol. 2009;4:876-883.

45. Auffan M, Rose J, Bottero JY, Lowry GV, Jolivet JP, Wiesner MR. Towards a definition of inorganic nanoparticles from an environmental, health and safety perspective. Nat Nanotechnol. 2009;4:634-641.

46. Puzyn T, Rasulev B, Gajewicz A, et al. Using nano-QSAR to predict the cytotoxicity of metal oxide nanoparticles. Nat Nanotechnol. $2011 ; 6: 175-178$.

\section{Dovepress}

Journal Citation Reports/Science Edition, EMBase, Scopus and the Elsevier Bibliographic databases. The manuscript management system is completely online and includes a very quick and fair peer-review system, which is all easy to use. Visit http://www.dovepress.com testimonials.php to read real quotes from published authors. 